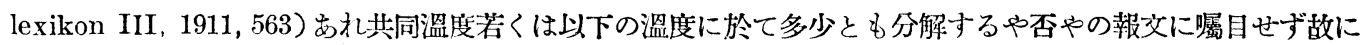
著者は上記の實驗施行に先立ちて本物質若くは之とアルコールとの混合が長時問の加熱によりて化學繥化を起 すべきや否やを寞驗したり

その結果を要約寸れば

1）加熱溫度 $100^{\circ} \mathrm{C}$ 以下なれば變化なし

2）加熱洔間短力ければ $130^{\circ} \mathrm{C}$ にても變化なし

3）アルコールが至純なれば $130^{\circ} \mathrm{C} に 1$ 時間加熱するも全く變化なきものの如し

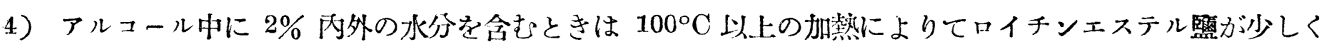

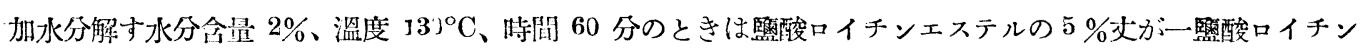
に變じたり

\title{
IV. 遷移溫度及遷移熱
}

上記の遷移溫度は單に溶解度曲線の交叉呚としてグラフ法によりて求めたるものなるが故に必ずしも $1-2^{\circ} \mathrm{C}$ 內外の誤差を否定する能はずこの故に著者は遷移點を精密に知らんが䉆及び同時に遷移熱の大小を概知せんが 雹め膨脸計による測定を企行したり

膨脹計の寸法は交献 (K. Arndt, Physik. Chem. Technik, II, 213) に從ひ之に $\alpha$ - 絬晶 $4 \mathrm{~g}$ 及流動パラ フィン $15 \mathrm{~g}$ を入れて恒溫槽中に長時間加熱し次に少しく高き溫度に長洔闍加熱し次第に此方法を反覆す

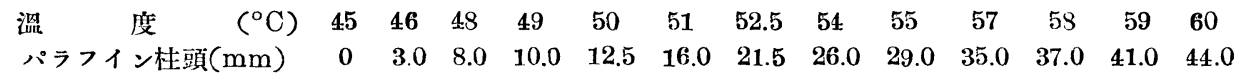

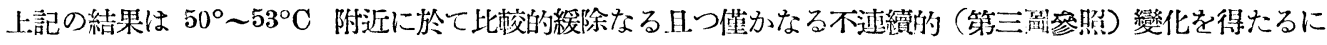

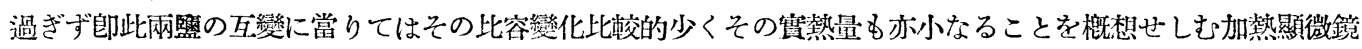
を用ひて遷移點を實測せんとする方法は目下續行中なり

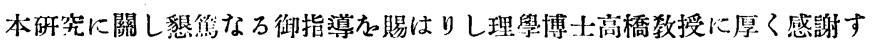

（早稳田大學理工學部應用化學研究空）（昭和五年五月一九日受理）

\section{蔴糖の轉化速度に關する研究（第三報） 粅インヴェルターゼに因る轉化速度}

工學士武富昇

䋶言

インヴェルターゼの硎究は從來多數あるも殆どいづれも酵母インヴェルターゼの咑究なり酤母インヴェルター ゼと楝インヴェルターゼと本質的に異なるものか 又は性質上の相㒉は吡に酵素の純粹度に因るものなるか一應 疑問に思はる〉も恐らくオイラー氏 (Euler: Chemie der Enzyme, dritte Auflage, 169)の云へる如く純粹 度に因るものに非ずして異なる酵素の特性に歸ず゙きものならむと思はる本報は䉽インヴェルターゼを使用し

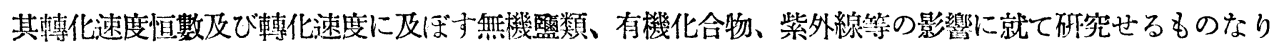




\section{萢料及び實驗裝置}

本寒驗に使用せる菣糖及び水は第一報（本誌，昭 $4,32 ， 891$ ）及第二報（本誌，昭 $5,33,321$ ）に述べた ると同栐の方法を以て精製せるものを使用せり数中にインヴェルターゼの存在する事は既に知らるつ所なるが 此インヴェルターゼか麵より分離せる市販タヂカアスターゼ中にアミラーゼと共に混合して存在するならむと 思ひ豫め市販タカデアスターゼを以て轉化試驗を行ひたるに多量のインヴェルターゼを含有する事を認めたり 故に本研究に於てはインヴェルターゼの原料としては直接麴を使用せずして市販タカヂアスターゼを用ひ是よ りインヴェルターゼを分滩情製せり郎ちタカデアスターゼ $28 \mathrm{~g}$ を $170 \mathrm{cc}$ の水に溶解し此溶液に對し約 $1 \%$ の トルオールを加へたる後 $N / 2$ 醋酸溶液 3 滴を加へて微酸性とし次に $25^{\circ} \mathrm{C}$ の恒温器中に 1 書夜放置して市販

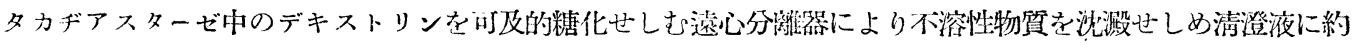

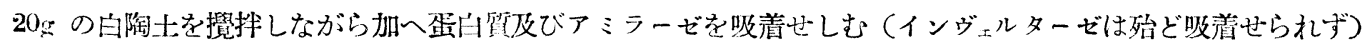

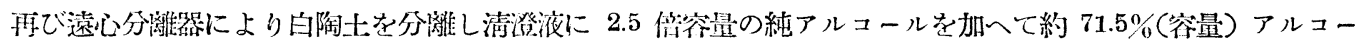
ル液と寸アルコールを加へたる後 3 分䦌放犆し上澄液を除去し沚澱を 150 或は $200 \mathrm{cc}$ の水に溶解しトルオ ールを $2 \mathrm{cc}$ 加へて冷藏庫中に 1 書夜放置せる後夷に透心分離器により不溶性物質を除去し透明なるインヴェル

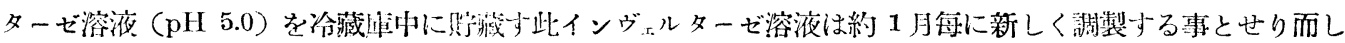

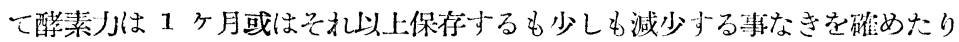

恒罚器及で檢糖器は第一報に記せるものと同樣のものを仙用せり

\section{粼インヴェルターゼに因る轉化速度恒數}

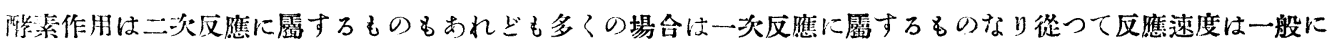
は次式方以て表す事施得

$$
\begin{aligned}
& \frac{d x}{d t}=k(a-x) \\
& k={ }_{t}^{1} \log _{e} \frac{a}{a-x} \quad \text { 或は } k=\frac{1}{0.4343 t} \log \frac{a}{a-x} .
\end{aligned}
$$

云ふ迄もなく $k$ は速度恒數にして $a$ は最初 17 小に存在せし作用物質 (Substrate) のモル數、 $x$ は分閣 に戀化したっ該物質のモル数なり

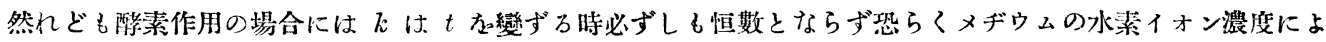

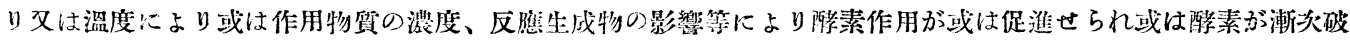

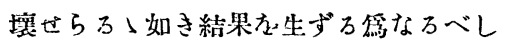

蕉糖の轉化这度恒數に就ては Hudson ( $J$. Ain. Chem. Soc., 1908, 30,1160), Michaelis (Biocibem. Zs.,

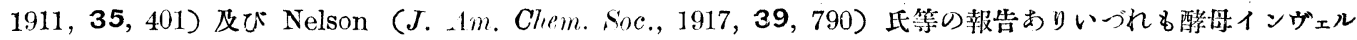

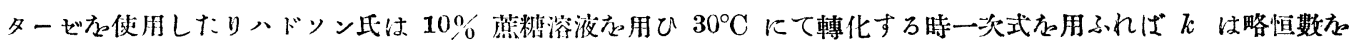

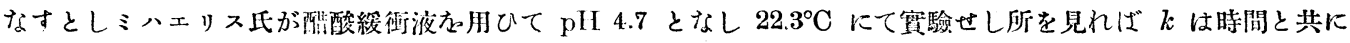

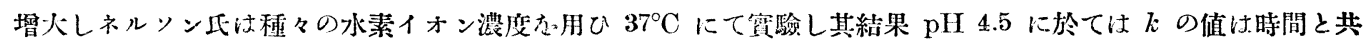
に增大し $\mathrm{pH} 4.5$ より大となれば即ち之より酸性が弱くなれば $k$ は略恒數かなし又 $\mathrm{pH}$ の值によりkは減少す 万事应示せり

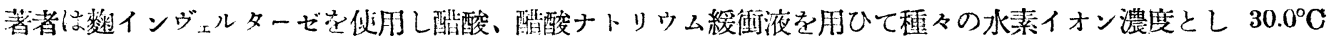

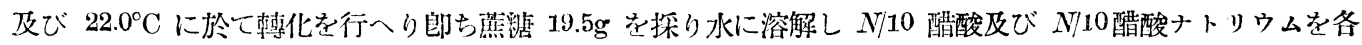
一这量を加へて任意の $\mathrm{pH}$ とし次でインヴェルターゼ溶液 $20 \mathrm{cc}$ を加へたる後更に水を加へて全體を 150cc とし よく混和与訧方に $\mathrm{M} / 5 \mathrm{Na}_{2} \mathrm{CO}_{3}$ 溶液 5ce をフラスコに取り置き是に前記の液 $2 \mathrm{cc}$ を直ちに加へてインヴ 
ルターゼの作用を止め又變旋光 (Mutarotation) を完結せしめて旋光度を測定し其值に 30/25 を乘じて最初の 旋光度と才殘りの夜は石英フラスコに入れ直ちに恒溫器中にて轉化を行ひ或時間の後再び前同樣にして其時の 旋光度を決定せり實驗結果は第一、第二、第三及び第四表に示す如し速洨恒數 $k$ は第一報中の (5) 式郎ち $k=\frac{1}{0.4343 t} \log \frac{r_{0}-r_{\infty}}{r-r_{\infty}}$ より之を求め $r_{\infty}$ は計算傅の $15.9^{\circ} \mathrm{V}$ を採れり

$$
\text { 第一表 }\left(30.0^{\mathrm{C}} \mathrm{C}\right)
$$

$\begin{array}{rcc}\text { 時間(分) } & \begin{array}{c}\text { 旋光度 } \\ \text { (Ventzke degree) }\end{array} \\ 0 & 49.80 & \\ 114 & 35.05 & 0.00223 \\ 179 & 30.50 & 0.00194 \\ 28 . & 26.32 & 0.00157 \\ & \text { 管 } & \text { 表 }\left(30.0^{\circ} \mathrm{C}, \mathrm{pH} 4.5\right)\end{array}$

$\begin{array}{ccc} & \\ \text { 時閆(分) } & \text { 旋光度 }(\mathrm{V} \text {. }) & k \\ 0 & 49.70 & \\ 71 & 38.55 & 0.00262 \\ 156 & 30.00 & 0.00229 \\ 216 & 25.90 & 0.00209 \\ 282 & 22.85 & 0.00187\end{array}$

第二表 $\left(30.0^{\circ} \mathrm{C}, \mathrm{pH} 4.7\right)$

$\begin{array}{rcc}\text { 時间(分) } & \text { 旋光度(V.) } & l i \\ 0 & 49.70 & \\ 94 & 35.65 & 0.00256 \\ 159 & 29.35 & 0.00234 \\ 230 & 21.90 & 0.00206 \\ 286 & 22.75 & 0.00187\end{array}$

第叫表 $\left(22.0^{\circ} \mathrm{C}, \mathrm{pH} 4.5\right)$

$\begin{array}{ccc}\text { 時䦐(分) } & \text { 旋光度(V.) } & k \\ 0 & 49.70 & \\ 102 & 40.70 & 0.00145 \\ 161 & 36.20 & 0.00143 \\ 220 & 32.50 & 0.00138 \\ 280 & 29.25 & 0.00133\end{array}$

上の表より知る如く敕インヴェルターゼに因る轉化の際は速度恒數 $k$ は時間が增加するに從ひ漸次減少する 事を認屯第一表は㗔衝液を加へざるものなりインヴェルターゼの最適水素イオン濃度と云はる〉 pH 4.5 に於 ても份 $k$ の值は時開と共に減少せり唯溫度が低き時郎ち $22.6^{\circ} \mathrm{C}$ にて $\mathrm{pH} 4.5$ の洔は $k$ の估は稍恒數に近し $40.0^{\circ} \mathrm{C} 、 50.0^{\circ} \mathrm{C}$ に於ける $k$ は第五表に示せりかくの如き高温に於ては $k$ の減少率は更に大なり之を以て視れ

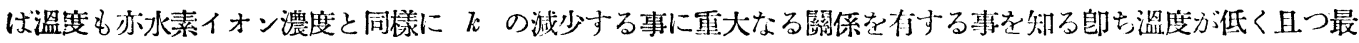
適水素イオン濃度の附近に於ては $k$ は恒數に近づくも一般には檞インヴェルターゼの場合はｋは時間の壖加 寸るに從ひて漸次減少すと云ふを得べし

\section{轉化速度に及ぼす溫度の影響}

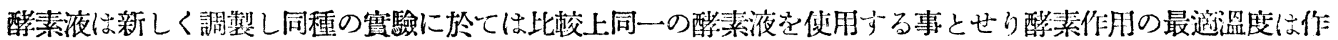
用時間の長短により異なるを以て本琠驗は溫度と時間を變化して旋光恔の減少を測定し其値より次の如くして 轉化せる蔴糖量 (g/100 cc) を決定せり

純蕉糖 $a \mathrm{~g}$ を水に溶解し次て醭素液を加へたる後正確に $100 \mathrm{cc}$ とし次で一定時間後旋光度を测定し $b^{\circ} \mathrm{V}$. (Ventzke degree) を得たりとすれば其時に於ける各糖分の量は次の如くして計算したり

$1^{\circ} \mathrm{V}$.at $20^{\circ} \mathrm{C}=0.2600 \mathrm{~g}$ sucrose in $100 \mathrm{cc}$

$1^{\circ} \mathrm{V} . "$ " $=0.3225 \mathrm{~g}$ glucose " "

$-1^{\circ} \mathrm{V} . "$ " $=0.1859 \mathrm{~g}$ fructose " "

旋光度 $\mathrm{b}^{\circ} \mathrm{V}$. を得たる時葡萄糖及び果糖の各々の量を $x \mathrm{~g}$ と寸机ば次式を拈

$$
\begin{aligned}
& b=\frac{a-2 x(0.95)}{0.26}+\frac{x}{0.3225}-\frac{x}{0.1859} \\
& 1494 x=600 a-15.6 b
\end{aligned}
$$

上の式より $x$ を算出する事を得而して轉化せる䓞糖量 (g/100cc) は $2 x \times 0.95$ 即ち $1.9 x$ なり

焦驗方法は前記の方法と略同漾にして唯此場命はいづれも醋酸、醋酸ナトリウム緩衝液を加へて $\mathrm{pH} 4.7$ と して䔈驗を行へり實驗結果は第五表及で第六言に示せる如し 


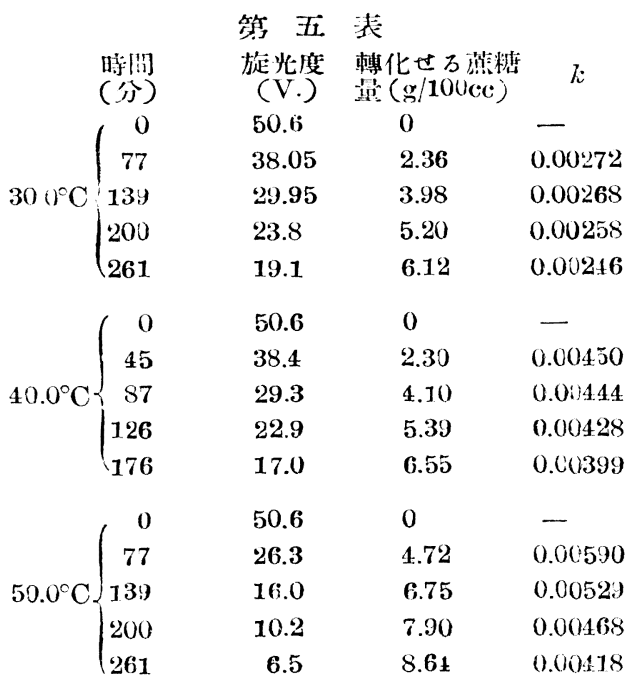

\begin{tabular}{|c|c|c|c|}
\hline & (照䦐) & 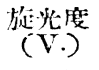 & 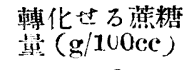 \\
\hline \multirow{4}{*}{$45.0^{\circ} \mathrm{C}$} & 0 & 50.6 & 0 \\
\hline & 80 & 26.7 & 4.62 \\
\hline & $\{142$ & 17.0 & 6.53 \\
\hline & 230 & 9.3 & 8.08 \\
\hline \multirow{6}{*}{$48.0^{\circ} \mathrm{C}$} & 0 & 50.6 & 0 \\
\hline & 30 & 39.5 & 2.09 \\
\hline & 61 & 30.2 & 3.94 \\
\hline & 123 & 18.3 & 6.28 \\
\hline & 182 & 11.5 & 7.62 \\
\hline & 228 & 8.25 & 8.26 \\
\hline \multirow{6}{*}{$55.0^{\circ} \mathrm{C}$} & 0 & 50.6 & 0 \\
\hline & 33 & 36.65 & 2.64 \\
\hline & 68 & $32.3 j$ & 3.50 \\
\hline & 128 & 26.9 & 4.58 \\
\hline & 191 & 24.0 & 5.15 \\
\hline & 253 & 22.35 & 5.47 \\
\hline \multirow{5}{*}{$60.0^{\circ} \mathrm{C}$} & 0 & 50.6 & 0 \\
\hline & 30 & 44.1 & 1.17 \\
\hline & 61 & 43.65 & 1.26 \\
\hline & 122 & 43.6 & 1.27 \\
\hline & 197 & 43.5 & 1.28 \\
\hline
\end{tabular}

第五表中の $k$ は第一表中の $k$ と同㧼にして算出せり又本報中の(1)式よりも計算したりしが近似值を得た

第 一 回

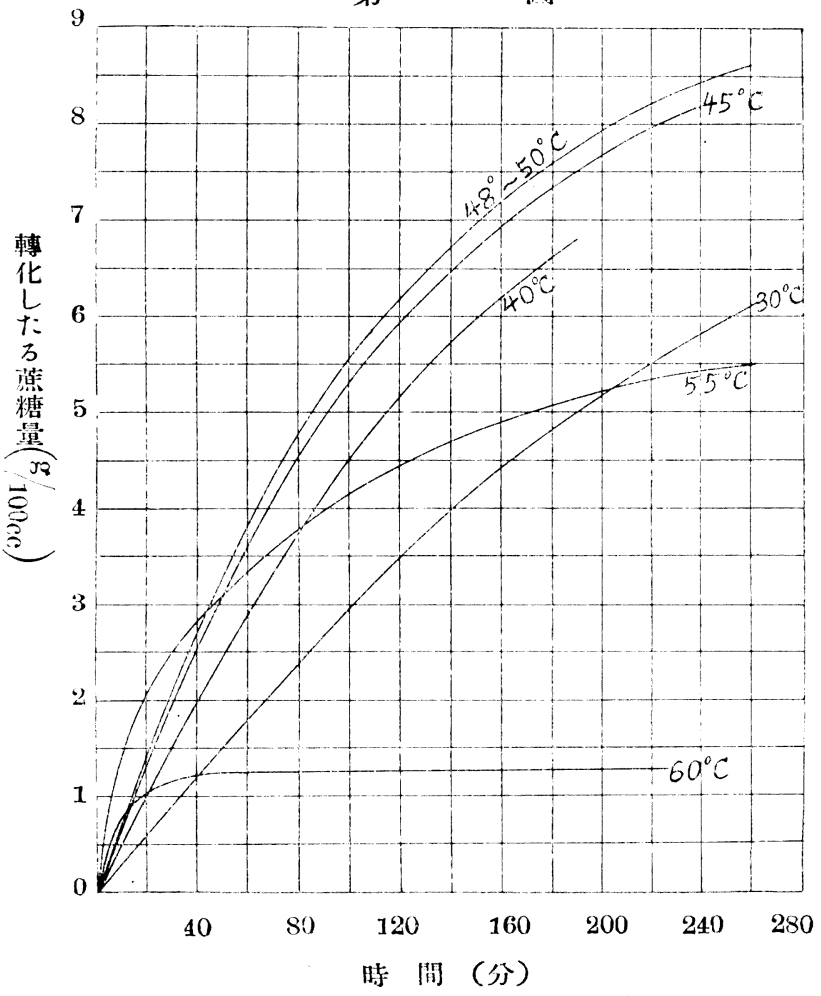

るを以て之を省略せり賽驗結果を滴示すれ ば第一阅の如し

饮ち時间短き時は最邀溫度は比較的高溫 に在り例一ば本翼驗に於ては 40 分以下の 時は最適溫度 $55^{\circ} \mathrm{C}$ 附近に住り然るに 40 分 闻以上の㭙は $48 \sim 50^{\circ} \mathrm{C}$ 以て最適溫度と 見て可なり程此最透溜度は水素イオン濃 度、亚孝の濃度、保護物質の存否等に因り 多少變化する事むるべし $60^{\circ} \mathrm{C}$ にては䤃素 の破壊速度は甚だ大にして3! 分後には殆 ど其作用力を失ふ

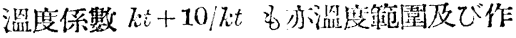

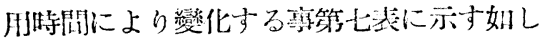

第 七 表 湿度俰數 $k t+10 / k t$

作用時间(分) $\quad 30 \sim 40^{\circ} \mathrm{C} \quad 10 \sim 50^{\circ} \mathrm{C}$

$\begin{array}{ccc}77 \sim 87 & 1.63 & 1.33 \\ 126 \sim 139 & 160 & 1.23\end{array}$

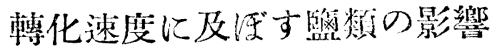

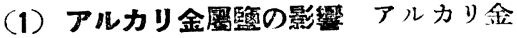
属の弱酸監は水溶液はアルカル性を呈する 
を以てインヴェルターゼの作用を阻害寸ることは勿論なり第一郝に於てアルカリ金屬の强酸監はそれ自身は轉

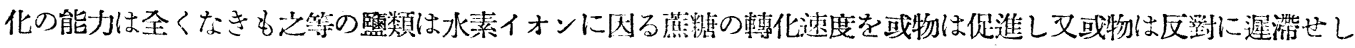

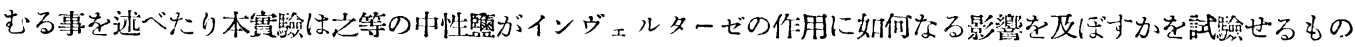

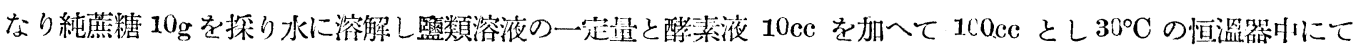

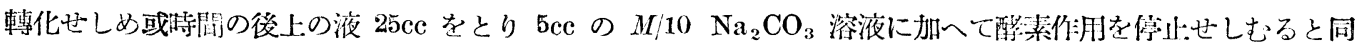

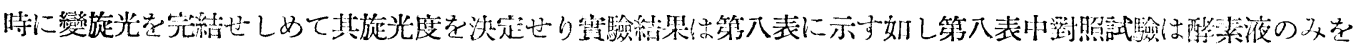

\begin{tabular}{|c|c|c|c|}
\hline 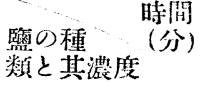 & 0 & 60 & 180 \\
\hline 對照試験 & $32.6^{\circ} \mathrm{V}$ & $24.1^{\circ} \mathrm{V}$ & $15.7^{\circ} \mathrm{Y}$ \\
\hline $0.01 N \mathrm{KCl}$ & " & 24.1 & 15.6 \\
\hline $0.1 N \mathrm{KCl}$ & " & 24.5 & 15.9 \\
\hline $0.02 N^{r} \mathrm{NaCl}$ & " & 23.7 & 14.8 \\
\hline $0.1 \quad N \mathrm{NaCl}$ & " & 24.1 & 15.1 \\
\hline $0.5 \quad N \mathrm{NaCl}$ & " & 24.8 & 16.0 \\
\hline $2 \quad N \mathrm{NaCl}$ & 32.2 & 26.6 & - \\
\hline $0.1 \mathrm{NK}_{2} \mathrm{SO}_{4}$ & 32.6 & 24.3 & 15.7 \\
\hline $0.5 \mathrm{~N} \mathrm{~K}_{2} \mathrm{SO}_{4}$ & "I & 24.6 & 15.9 \\
\hline $0.02 N \mathrm{KNO}_{3}$ & " & 24.1 & 15.7 \\
\hline $0.1 N \mathrm{KNO}_{3}$ & " & 24.5 & 15.9 \\
\hline
\end{tabular}
加へ㹂颣穵加へざるものなり

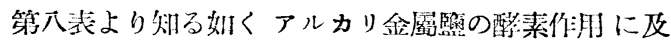

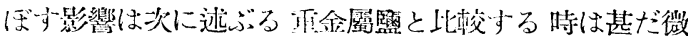

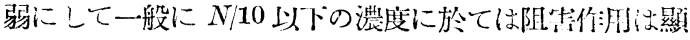
著ならずと云う事を得べしアルカリ金屬盟は濃厚とな

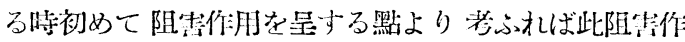

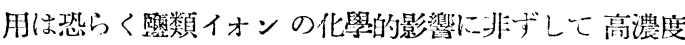
の䉆インヴェルターゼの分散度を減少やししもる絬果なら むと考へらる酩素作用は酵菜の裴面作用に因るものな

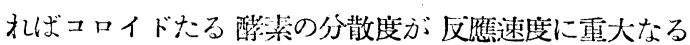

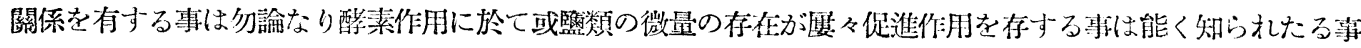

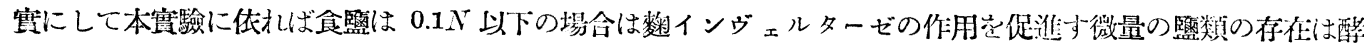
素が電姚的性質を保さコロイド的分散を維持するに必要なるものなるべし

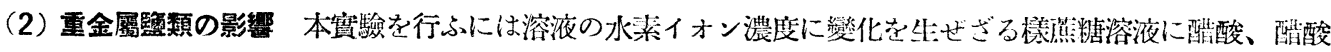
ナトリウム楥衝液を加へて pH4.7としたる後所琶の暨類を加へ次でインヴェルターゼ溶液を加へて䡳化を行へ

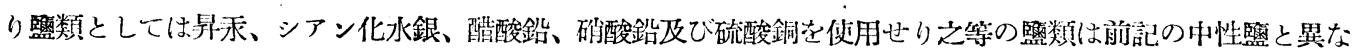

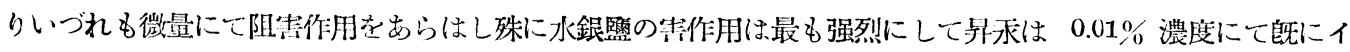

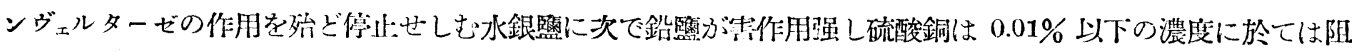
害作用は殆ど認专る事能はず

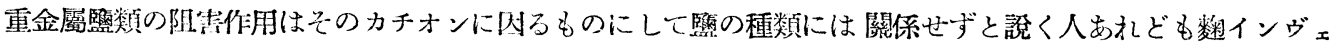

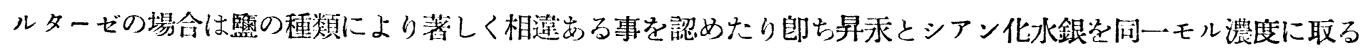

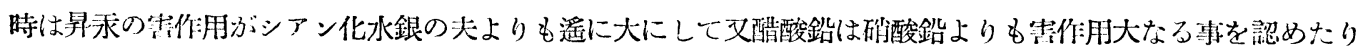

\section{轉化速度に及ぼす有機化合物の影篭}

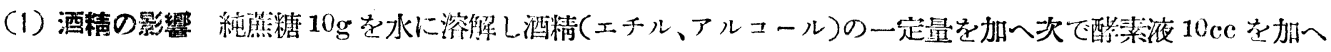
て $100 \mathrm{ccc}$ とし $30.0^{\circ} \mathrm{C}$ の恒溫器中て轉化せしも 90 分の後上の液 $20 \mathrm{cc}$ を $5 \mathrm{cc}$ の $M / 10 \mathrm{Na}_{2} \mathrm{CO}_{3}$ 溶液に加へて醉 索作用を止め又變施光を完結せしめて旋光度を測定せり 旋光度の減少より計算により轉化せる覧糖量（g/100 cc）在決定せり賽驗結果は第九表に示寸如し

第九表中比俳力は酒精を含まざる水中にて轉化せし蔴糖量を 100 とし之に璟して其比を求めたるものなり 此表より知る如く猌インヴェルターゼの轉化速度に及ぼす酒精の影響は意外に弱く酒精含量が $25 \%$ に達するも 比作用力は僅 $15.7 \%$ 減少せるに過ざざるなり酒精による阻苦倠朋は主としてインヴェルターゼの分散度を減ず 
第 九 表

酒精の纤星
$\%$
0
5
10
轉化せし蒫糖量 (g/100cc)
4.67
4.66
4.47

比作用力
100
99.8
95.7

酒精の容量
$\%$
15
20
25

25

$\begin{array}{cc}\begin{array}{c}\text { 轉化せし蔗糖量 } \\ (\mathrm{g} / 100 \mathrm{cc})\end{array} & \text { 比作用力 } \\ 4.33 & 92.9 \\ 4.14 & 88.7 \\ 3.94 & 84.3\end{array}$.

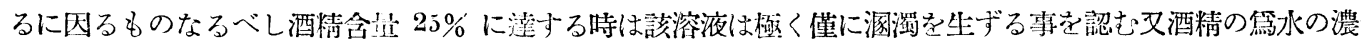
度の減少も亦轉化速度の減少せし一つの原因と考ふる事老得べし醏素は一種の雨性電解質にして其作用は解㒕

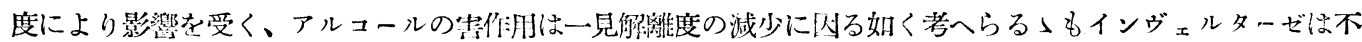
解獭分于が活性なりと云はる〉故に解維度が減少する洔は其作用は却つて促進せられざるべからず

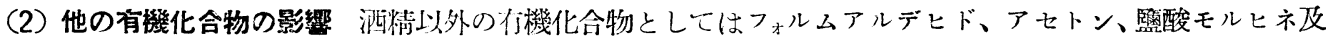

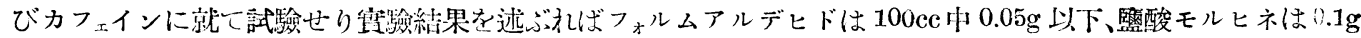

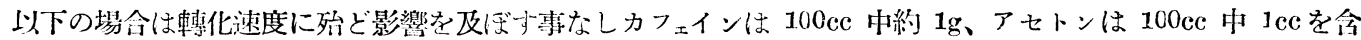
光場合にも阻年作用を認むる事能はず酒精及び上に擧げたる存機化合物中害作用の最も大なるはフォルムアル

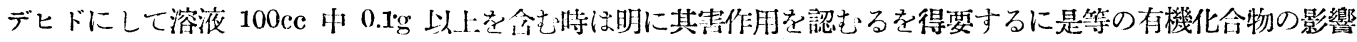

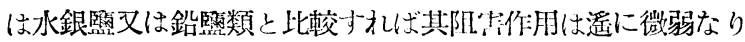

\section{紫外線の影響}

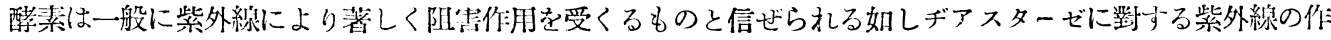
用を矿究したるものによれば最邀水素イオン濃度に於て最もよく阻害せられ又エオシンの如きフォトセンシタ

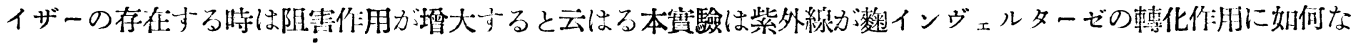
る程度の点倠朋を及ぼすかを試驗せむが䉆に行ひたるものなり

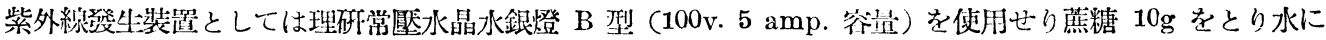
溶解しインヴェルターゼ溶液 $10 \mathrm{cc}$ を加へて $100 \mathrm{cc}$ としよく混和したる後直ちに此溶液の 25ec 宛を水晶製 フラスコと磁製フラスコにとりてフラスコはコルクを以て密閉し二つのフラスコは同一の器に入れたる一定溫 度の清水の中に沒し光源より約 $20 \mathrm{~cm}$ の距維に於て科め上より紫外線に照射せり一定時間の後各フラスコに

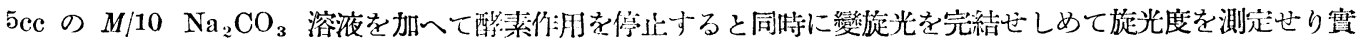
驗結果は第十表に示寸如し第十表中照射前の旋光度は藻䌅 $10 \mathrm{~g}$ を水に溶解しインヴェルターゼ溶液 $10 \mathrm{cc}$ を加 へて 100cc としたる後直ちに其 25cc をとりて 5cc の $M / 10 \mathrm{Na}_{2} \mathrm{CO}_{3}$ 溶液に加へて旋光度を決走せるものな り實驗番號 3 は醋酸、醋酸ナトリウム綏街液を加へて $\mathrm{pH} 4.7$ として紫外線に當てたるものにして顀驗番號 4 は蔍糖がインヴェルターゼに對し保護作月を哭すやも知れずと考へらるつを以て豫めインヴェルターゼ溶液 $5 \mathrm{cc}$ 宛を水晶フラスコと磁製フラスコに大れ約 $17^{\circ} \mathrm{C} に て 95$ 分間紫外緗に當てたる後純哭糖溶液 $(10 \mathrm{~g} / 100 \mathrm{cc})$

\begin{tabular}{|c|c|c|c|c|c|}
\hline \multirow{2}{*}{$\begin{array}{l}\text { 㯰驗 } \\
\text { 號 }\end{array}$} & \multirow{2}{*}{$\begin{array}{c}\text { 照射時们 } \\
\text { (分) }\end{array}$} & \multirow{2}{*}{$\begin{array}{l}\text { 溶液 } 9 \\
\text { 滥度 }\left({ }^{\circ} \mathrm{C}\right)\end{array}$} & \multirow{2}{*}{$\begin{array}{l}\text { 照射前 } 9 \\
\text { 旋光度 (V.) }\end{array}$} & \multicolumn{2}{|c|}{ 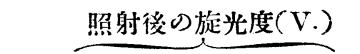 } \\
\hline & & & & 水晶フラスコ & 磁製フラス \\
\hline 1 & 103 & 20 & 32.8 & 25.9 & 25.9 \\
\hline 2 & 250 & 20 & 32.8 & 19.1 & 19.1 \\
\hline 3 & 120 & 17 & 32.8 & 25.5 & 25.5 \\
\hline 4 & 120 & 17 & $\Varangle 7.4$ & 19.7 & 19.7 \\
\hline 5 & 120 & 18 & 32.8 & $2 \overline{0} .7$ & 25.7 \\
\hline
\end{tabular}


を $25 \mathrm{cc}$ 宛加へ再び紫外線に:120 分間照射せるものなり又赛驗番號 5 は純蕉糖10g を水に溶解しエオシン溶 液 (1:4000) 1 $1 \mathrm{cc}$ 加へ次でインヴェルターゼ溶液 $10 \mathrm{cc}$ を加へ $100 \mathrm{cc}$ とし此溶液を前の如くして紫外線に照 射せり郎ち此場合はエオシンをフォトセンシタイザーとして使用せり

以上の賽驗結果より視る時は䊩インヴェルターゼに因る蔗糖の 轉化速度は紫外線に因り影響せられずと云ふ。 事を得又燕糖を含まずして赖インジェルターゼのみを含屯水溶液を豫め紫外線に 95 分間當てたる後哭糖の轉化 を行はしめたるも其力が減少する事なきを認めたり一般に䤃素は其純粹度が高くなるにつれ漸次不安定となる 故に極めて純粹なる場合紫外線の作用に就ては明言するを得ざれども普通には顂インヴェルターゼは紫外線に 對して相裳に安定にして破壞作用を受くる事甚だ少しと云ふ事を得べし

總括

（1）種々の水素イオン濃度及び溫度に於て麳インヴェルターゼに因る轉化速度恒數を測定せり而して速度恒 數は一次反應の式を邀用すれば一般に時間の墂加寸るに從ひ漸次減少寸る事を認めたり

(2) 轉化速度と溫度との關係を硎究し粷インヴェルターゼの最適溫度は作用時間 40 分以下の場合は $55^{\circ} \mathrm{C} 、$ 40 分以上數時間に亘る時は $48^{\circ} \sim 50^{\circ} \mathrm{C}$ とすべき事を見出せり

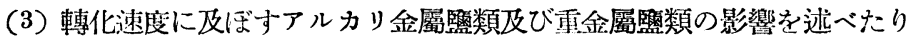

（4）轉化速度に及ぼす酒精、フォルムアルデヒド、アセトン、アルカロイド等の影響を述べたり

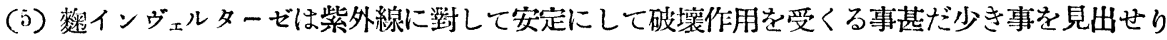

附記 本研究は三浦甲辰郎氏の助力か受けたり著者は玆に同氏に深謝の意妾表す

（東京帝國大學工學部售用化學科油脂研究室）（昭和五年五月二八六受理）

\section{斜方沸石の水分並に二三の性質に就て}

工學搏士 田 中 芳 雄
工學士 中 村 三 男

(1) 緒 $\overrightarrow{\overline{\vec{n}}}$

斜方沸不はゼオライト屬の 1 種にして $\left(\mathrm{Ca} \mathrm{Na} \mathrm{Na}_{2}\right) \mathrm{O} \cdot \mathrm{Al}_{2} \mathrm{O}_{3} \cdot 4 \quad \mathrm{SiO}_{2} \cdot 6 \mathrm{H}_{2} \mathrm{O}$ なる組成を有し正 6 面跤晶系の透

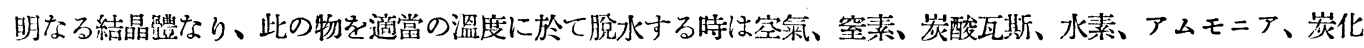
水素、水、メチルアルュール、エチルアルコール、蟻酸等の瓦斯文は蒸氣を收著する性質あり（R. Seelinger, Plbysik. Z., 1921, 22, 563; R. Nacken and W. Wolff, Centr. Mineral Geol., 1921, 364-72; 388-94; O. Weigel und E. Steinhoff, $Z$. Krit., 1925, 61, 125-54; F. Simon, Z. Phy $i$ il. Chem., 1928, 132, 456; 鮫島實三郎氏、Bull. Chem. Soc. Japan., 1928, 4, No. 4; O. Schmidt, Z. Physik. Chem., 1928, 133, 263) 此の物が溶液中より色素を吸着する能力おりや否やに就ては未だ䂙究あるを見ず、其の加熱減量に就ては二 三の報告あれども庴範なる溫度範圍に互り測定せられたるもの無く且つ其の脫水曲線は或は速續的なりとし或 は多少階段的なりとし未だ確說なし、本研究は高溫用化學天科に依る斜方沸石の脫水過程、科方沸石の膯色能 及び二、三の性質及び斜方沸石より得たる珪酸ゲルの脫色能に關するものなり 